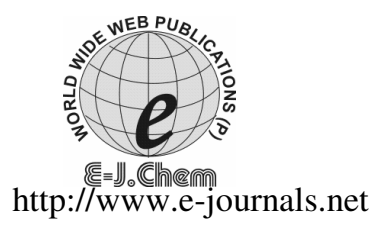

ISSN: 0973-4945; CODEN ECJHAO

E-Journal of Chemistry 2009, 6(S1), S12-S16

\title{
Effect of Current Density on the Anodic Behavior of Zircaloy - 2 and Titanium-A Comparative Study
}

\author{
N.N.S. APARNA and CH ANJANEYULU \\ Department of Chemistry, University College for Women, \\ Osmania University. Koti, Hyderabad, Andhra Pradesh, India. \\ nnssaparna@yahoo.co.in
}

Received 14 April 2009; Accepted 10 June 2009

\begin{abstract}
The kinetics of anodic oxidation of zircaloy- 2 and titanium have been studied at current densities ranging from 2 to $12 \mathrm{mAcm}^{-2}$ at room temperature in order to investigate the dependence of ionic current density on the field across the oxide film. Thickness of the anodic films were estimated from capacitance data. The formation rate, current efficiency and differential field were found to increase with increase in the ionic current density for both zircaloy-2 and Titanium. Plots of the logarithm of formation rate $v s$ logarithm of the current density are fairly linear. From linear plots of logarithm of ionic current density vs differential field and applying the Cabrera-Mott theory, the half-jump distance and the height of the energy barrier are deduced and compared.
\end{abstract}

Keywords: Anodization, Current density, Differential field, Cabrera-Matt theory, Zircaloy-2 and Titanium.

\section{Introduction}

It is well known that when valve metals such as zirconium, its alloys and titanium are anodically polarized, interference-coloured oxide films are formed. Smooth and mechanically perfect anodic films can act as dielectrics in capacitors. The phenomenon of anodic oxidation plays a basic role in micro-circuitory ${ }^{1}$ and in thin film methods ${ }^{2}$. Anodic films formed in suitable electrolytes and in suitable conditions have versatile applications as resistors, dielectrics, reflectors, rectifiers, semiconductors and photo anodes etc.

Gunther schultze and Betz ${ }^{3}$ were the first to investigate the kinetics and mechanism of the anodic oxidation of metals. Temperature and current density were found to exert a marked influence on the anodizing characteristics of metals ${ }^{4}$ such as $\mathrm{Ti}, \mathrm{Zr}$ etc. Raghunath Reddy et al. ${ }^{5}$ have reviewed the work in $\mathrm{Zr}-4$ and $\mathrm{Nb}$ from various view points. Shobharani et al. ${ }^{6}$ have similar results in growth kinetics of titanium.

In the present work, an attempt is made to study the effect of current density on the kinetics of formation of oxide films on zircaloy- 2 and titanium in $0.1 \mathrm{M}$ solutions of picolinic acid, sodium succinate and sodium methoxide. 


\section{Experimental}

The specimens used in the present work were punched from $0.2 \mathrm{~mm}$ thick, annealed rolled sheet of zircaloy-2 supplied by Nuclear Fuel Complex, Hyderabad as gift sample and 99.98\% pure titanium is gifted by Midhani, Hyderabad. zircaloy-2 is an alloy of zirconium with tin (1.20-1.70 Wt.\%) and Chromium (0.05-0.15 Wt.\%) as major impurities.

The specimens had a working area of $1 \mathrm{~cm}^{2}$ on each side and a tag $2 \mathrm{~cm}$ long. The specimens were polished to mirror finish by using chemical polishing mixtures, which considered of concentrated $\mathrm{HF}$ and $\mathrm{HNO}_{3}$ for zircaloy-2 and $\mathrm{HF}, \mathrm{HNO}_{3}$ and $\mathrm{H}_{2} \mathrm{SO}_{4}$ for titanium in definite volume ratios. Adams et al. ${ }^{7,8}$ and Willis et al. ${ }^{9,10}$ used chemically polished specimens which gave higher values for current efficiency at higher current densities. For anodization, a closed cell of $100 \mathrm{~mL}$ pylex glass beaker was used. The cathode was a platinum mesh of $20 \mathrm{~cm}^{2}$ superficial area, specifically chosen to make the double layer capacitance as large as possible.

The constant current generator used was a stabilized power supply unit (powertronics, Hyderabad) capable of supplying constant current in the 0-100 mA range. Capacitance measurements were made with a digital LCR meter (Vasavi Electronics, Hyderabad). Current was measured on a digital milliammeter and the potential directly across the cell on a digital voltmeter. Thicknesses of the anodic films were estimated from capacitance measurements. For this, the constant current was interrupted at regular voltage increments $(20 \mathrm{~V})$ by reversing a DPDT switch. An interval of about $30 \mathrm{~s}$ was allowed to lapse prior to reading capacitance data.

\section{Results and Discussion}

\section{Formation rate - current density relationship}

The kinetics of the anodic oxidation of zircaloy- 2 and titanium were studied in $0.1 \mathrm{M}$ solutions of picolinic acid, sodium succinate and sodium methoxide at constant current densities ranging from 2 to $12 \mathrm{~mA} \mathrm{~cm}^{-2}$ and at room temperature. The formation rate (dv/dt) was estimated from plots of formation voltages $v s$ time drawn at each current density for these electrolytes. The plots of log formation rate $v s \log$ current density are found to be linear, as shown in Figure 1 values of the slopes and intercepts in the plots are given in Table $1 \& 2$. The formation rate is expressed in $V \cdot s^{-1}$ and the current density in mA.cm ${ }^{-2}$.

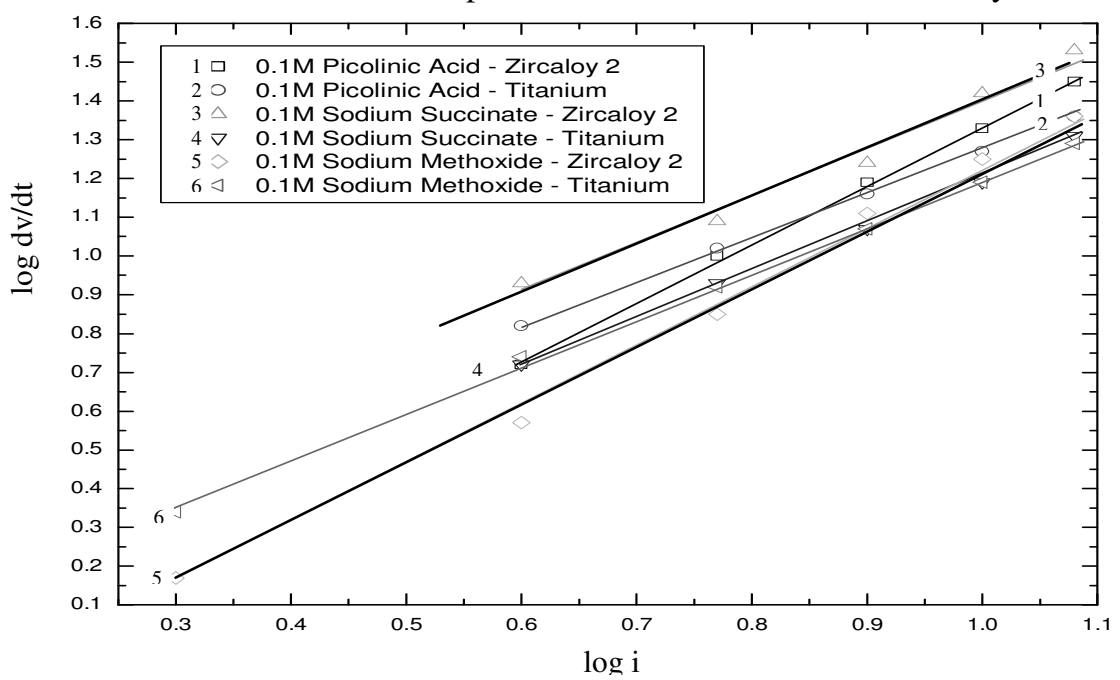

Figure 1. Plots of logarithm of formation rate $v s$. logarithm of current density. 
Table 1. Parameters in eq.(1) for zircaloy - 2.

\begin{tabular}{lcc}
\hline Electrolyte & Slope $(\mathrm{b})$ & Intercept $(\log \mathrm{a})$ \\
\hline Picolinic acid & 1.34 & 3.01 \\
Sodium succinate & 1.85 & 4.12 \\
Sodium methoxide & 1.44 & 3.13 \\
\hline
\end{tabular}

Table 2. Parameters in eq. (1) for titanium.

\begin{tabular}{lcc}
\hline Electrolyte & Slope $(\mathrm{b})$ & Intercept $(\log \mathrm{a})$ \\
\hline Picolinic acid & 1.03 & 2.33 \\
Sodium succinate & 1.15 & 2.49 \\
Sodium methoxide & 1.25 & 2.70 \\
\hline
\end{tabular}

The linearity between $\log (\mathrm{dv} / \mathrm{dt})$ and $\log$.i. shows that they are related by the empirical relation,

$$
\mathrm{dv} / \mathrm{dt}=\mathrm{a}(\mathrm{i})^{\mathrm{b}}
$$

Where, $a$ and $b$ are constants. A similar relationship was given by Vermilyea ${ }^{11}$ for the dependence of $\mathrm{d} \delta / \mathrm{dt}$ on $i$ for titanium, where $\delta$ is the thickness of the oxide film. The theoretical basis for the empirical relationship was given by Ammar and Kamal ${ }^{12}$ and Lavrenko and Chekhovskii ${ }^{13}$. Ammar and $\mathrm{Kamal}^{12}$ found that the values of slopes were independent of acid concentration in $\mathrm{H}_{2} \mathrm{SO}_{4}, \mathrm{HNO}_{3}$ and $\mathrm{HCl}$, whilst in $\mathrm{H}_{3} \mathrm{PO}_{4}$, the value was found to vary with the acid concentration. Similar linear relationships were established by Anjaneyulu and Syamala Devi et al. ${ }^{14}$ for titanium in electrolytes such as propionic acid and ammonium citrate.

\section{Ionic current density and differential field strengths}

The growth kinetics involves the study of variation of differential field with the ionic current density and calculation of kinetic parameters half jump distance (a) and height of the energy barrier (W) assuming that the rate determining step lies at the interfaces or within the bulk of the oxide. In the present study it was assumed that the highest energy barriers are situated at the interfaces and that the Cabrera-Mott theory was applicable. From plots of formation voltage rate, current efficiency, ionic current density and differential field (in case of titanium, unitary field) were calculated for zircaloy- 2 and $\mathrm{Zr}-\mathrm{Nb}$ (only for sodium methoxide) and titanium in the three electrolytes (Tables 3, $4 \& 5$ ). The current efficiency and field strength can be seen to be increasing with increasing current density. Plots of log ionic current density (i) vs. unitary field (F) were drawn for each current density and were found to be fairly linear.

Table 3. Data on the anodization of $\mathrm{Zr}-2$ and $\mathrm{Ti}$ in $0.1 \mathrm{M}$ picolinic acid.

\begin{tabular}{ccccccc}
\hline \multirow{2}{*}{$\begin{array}{c}\text { Current } \\
\text { density } \\
\text { mAcm }\end{array}$} & \multicolumn{2}{c}{$\begin{array}{c}\text { Formation rate } \\
\text { V.s }^{-1}\end{array}$} & \multicolumn{2}{c}{ Zircaloy-2 } & Titanium \\
\cline { 2 - 6 } & & Ti & $\begin{array}{c}\text { Current } \\
\text { efficiency, \% }(\eta)\end{array}$ & $\begin{array}{c}\text { Ionic current } \\
\text { density }\end{array}$ & $\begin{array}{c}\text { Differential } \\
\text { field }\end{array}$ & $\begin{array}{c}\text { Unitary } \\
\text { fields }\end{array}$ \\
\hline 4 & 0.53 & 0.67 & 41.3 & 1.65 & 5.72 & 3.10 \\
6 & 1.01 & 1.05 & 50.4 & 3.02 & 5.95 & 3.25 \\
8 & 1.57 & 1.47 & 55.5 & 4.44 & 6.18 & 3.40 \\
10 & 2.17 & 1.90 & 61.1 & 6.11 & 6.35 & 3.52 \\
12 & 2.86 & 2.34 & 65.2 & 7.82 & 6.54 & 3.62 \\
\hline
\end{tabular}


Table 4. Data on the anodisation of $\mathrm{Zr}-2$ and $\mathrm{Ti}$ in $0.1 \mathrm{M}$ sodium succinate.

\begin{tabular}{cccccc}
\hline & \multicolumn{2}{c}{ Zircaloy - 2} & \multicolumn{2}{c}{ Titanium } \\
\hline $\begin{array}{c}\text { Current } \\
\text { Density }\end{array}$ & $\begin{array}{c}\text { Formation } \\
\text { Rate dv/dt, Vs }\end{array}$ & $\begin{array}{c}\text { Current } \\
\text { Efficiency }(\eta), \%\end{array}$ & $\begin{array}{c}\text { Differential } \\
\text { Field } \\
\mathrm{F}_{\mathrm{D}}, \mathrm{MVcm}^{-1}\end{array}$ & $\begin{array}{c}\text { Formation } \\
\text { Rate dv/dt, Vs }\end{array}$ & $\begin{array}{c}\text { Unitary Field } \\
\mathrm{F}_{\mathrm{U}}, \mathrm{MVcm}^{-1}\end{array}$ \\
\hline 4 & 0.87 & 34.1 & 5.72 & 0.60 & 2.50 \\
6 & 1.25 & 45.3 & 6.36 & 0.77 & 2.68 \\
8 & 1.75 & 59.9 & 6.73 & 0.90 & 2.78 \\
10 & 2.65 & 68.2 & 6.94 & 1.00 & 2.88 \\
12 & 3.43 & 72.5 & 7.05 & 1.08 & 3.20 \\
\hline
\end{tabular}

Table 5. Data on the anodisation of $\mathrm{Zr}-2$ and $\mathrm{Ti}$ in $0.1 \mathrm{M}$ sodium methoxide.

\begin{tabular}{cccccc}
\hline \multicolumn{3}{c}{ Zircaloy - 2 } & \multicolumn{2}{c}{ Titanium } \\
\hline $\begin{array}{c}\text { Current } \\
\text { Density }\end{array}$ & $\begin{array}{c}\text { Formation } \\
\text { Rate dv/dt, VS }\end{array}$ & $\begin{array}{c}\text { Current } \\
\text { Efficiency }(\eta), \\
\%\end{array}$ & $\begin{array}{c}\text { Differential } \\
\text { Field } \\
\mathrm{F}_{\mathrm{D}}, \mathrm{MVcm}^{-1}\end{array}$ & $\begin{array}{c}\text { Formation } \\
\text { Rate } \\
\mathrm{dv} / \mathrm{dt}, \mathrm{VS}^{-1}\end{array}$ & $\begin{array}{c}\text { Unitary Field } \\
\mathrm{F}_{\mathrm{U}}, \mathrm{MVcm}^{-1}\end{array}$ \\
\hline 2 & 0.15 & 29.5 & 4.54 & 0.22 & 2.04 \\
4 & 0.38 & 36.2 & 4.68 & 0.55 & 2.55 \\
6 & 0.72 & 44.1 & 4.87 & 0.84 & 2.59 \\
8 & 1.30 & 56.5 & 5.08 & 1.20 & 2.78 \\
10 & 1.78 & 61.1 & 5.20 & 1.58 & 2.93 \\
12 & 2.33 & 65.4 & 5.32 & 1.97 & 3.04 \\
\hline
\end{tabular}

Using the empirical relation proposed by Guntherscheltz and Betz (3),

$$
i_{i}=A_{i} \exp .\left(B_{i} F\right)
$$

The temperature dependent constants $A_{i}$ and $B_{i}$ were found:

Comparing with Cabrera - Mott equation ${ }^{15}$,

$$
\mathrm{i}_{\mathrm{i}}=\text { nvq. } \quad \text { exp. }[(-\mathrm{W}-\mathrm{qaF}) / \mathrm{kT}]
$$

With eq. (1), the expressions for $A_{i}$ and $B_{i}$ can be written as

$$
\begin{aligned}
\mathrm{Ai} & =\eta v q / \exp .(-\mathrm{W} / \mathrm{KT}) \\
\mathrm{B}_{\mathrm{i}} & =\mathrm{qa} / \mathrm{kT}
\end{aligned}
$$

The value of half-jump distance, ' $a$ ' deduced in these electrolytes for zircaloy- 2 is larger than the mean separation of oxygen ion in $\mathrm{ZrO}_{2}\left(1.66 \mathrm{~A}^{\circ}\right)$. However, the value of ' $\mathrm{a}$ ' is comparable to the half lattice parameter of cubic modification of $\mathrm{ZrO}_{2}$. Moreover, the values of kinetic parameters ' $\mathrm{a}$ ' and $\mathrm{W}$ obtained in the present work are comparable with the values for zirconium and its alloys.

The values of $\mathrm{W}$ obtained for anodic film formation are in good agreement with that obtained by earlier workers in $\mathrm{Zr}-4$ and $\mathrm{Nb}$.

\section{Conclusions}

The kinetic results are seen to have improved with zircaloy-2 in sodium succinate and picolinic acid when compared to sodium methoxide. Log-log relationship is found between the formation rate and current density. An exponential dependence of ionic current density on differential field was observed. The variations in half-jump distance and weight of the energy barrier are explained in terms of the movement of mobile ions via interstices and grain boundaries. 


\section{Acknowledgement}

The authors are grateful to Prof. L.N. Sharada, Head, Department of Chemistry, University College for Women, Koti, Osmania University for her keen interest and encouragement. The authors are also thankful to Nuclear Fuel Complex and Midhani, Hyderabad for generous help in providing zircaloy-2 and titanium samples.

\section{References}

1. Mclean, Proceedings of the National Electronics Conference, 1960, p 206.

2. Wilcock W L, Emberson D Land Weekly B, Institute Radio Engineers, Trans on Nuclear Science, NS-7, 1960, p126.

3. Gunther Schutze A and Betz H, Electrolytkondensatoron, $2^{\text {nd }}$ Edn., Berlin, Herbertcram, 1952.

4. $\quad$ Lakhiani D M and Sherier L L, Nature, 1960, 188, 49.

5. Raghunath Reddy G, Lavanya A and Anjaneyulu Ch, Bulletin of Electrochemistry, 2004, 20(8), 337-341.

6. Shobharani P, Rao, Prabhakar M V, Sastry K S, Transactions of SAEST, 2003, 38(2) 59-60.

7. Adams G B, Van Rysell Lerghe P and Moraghini M, J Eletrochem Soc., 1955, 102, 502.

8. Adams G B, Lee T S, Drago Nor S M and Van Rysselberghe P, J Electrochem Soc., $1958, \mathbf{1 0 5}, 660$.

9. Willis Jr A C, Adams G M and Van Ryssel berghe P, Electrochim Acta, 1964, 9, 79.

10. Willis Jr G C, Adams G M and Van Ryssel berghe P, Electrochim Acta, 1964, 9, 931.

11. Vermilyea D A, Advances in Electrochemistry and Electrochemical Engineering, Interscience, Ney York, 1963, 3, 211.

12. Ammar I A and Kamal I, Electrochim Acta, 1971, 16, 1539.

13. Lavrenko V and Chekhovskit A, Ukr Khim Zh., 1964, 30, 788.

14. Syamala Devi K, Anjaneyulu Ch and SastryK S, J Electrochem Soc India, 1986, 35, 29.

15 Lavanya A, Galvanostatic Anodic Polarization Of Zirconium Alloys,Tantalum and Niobium-Kinetic Studies, Ph.D. Thesis, Osmania University, India, 2005. 


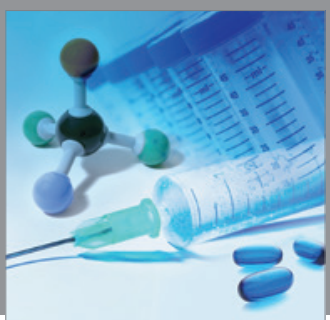

International Journal of

Medicinal Chemistry

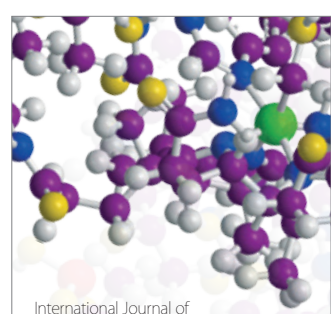

Carbohydrate Chemistry

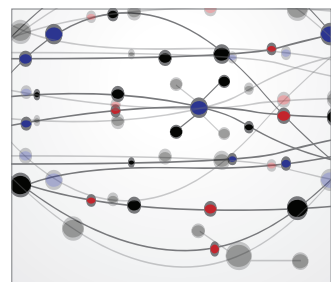

The Scientific World Journal
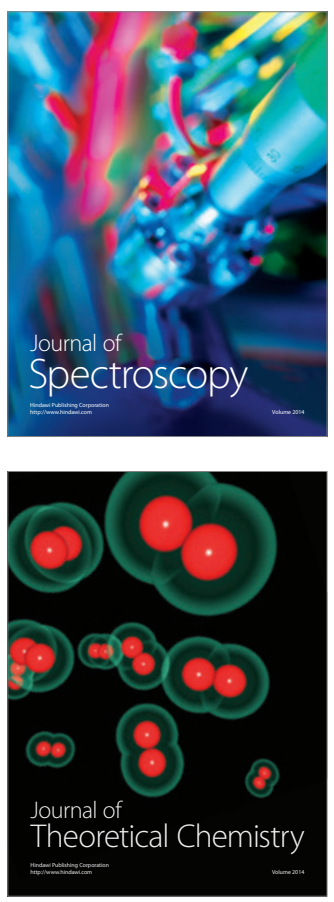
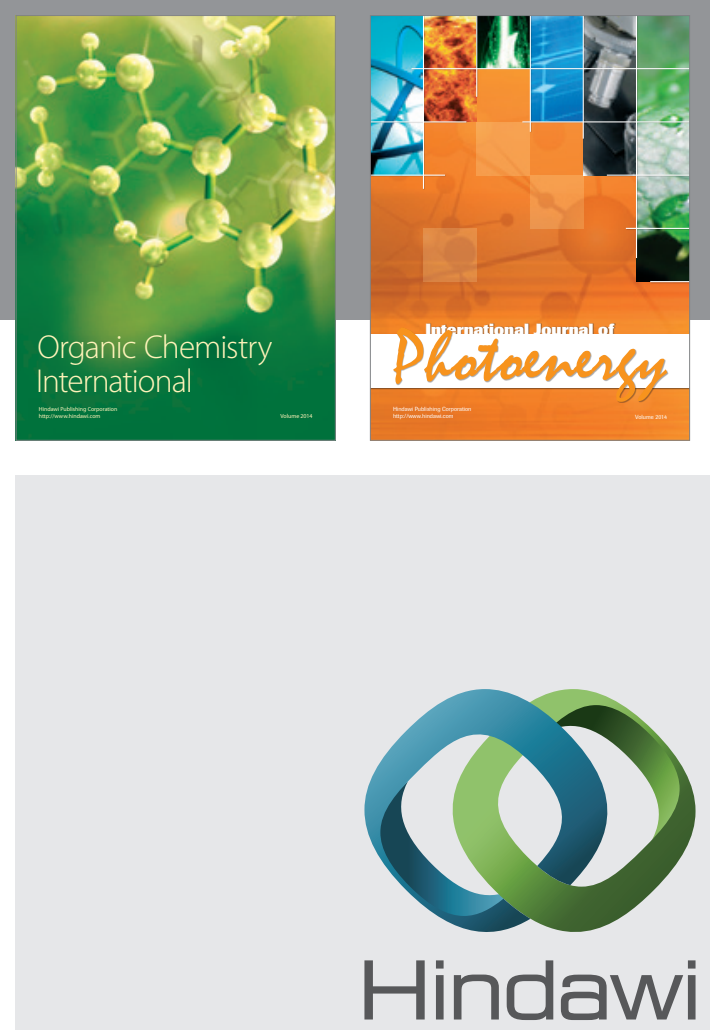

Submit your manuscripts at

http://www.hindawi.com
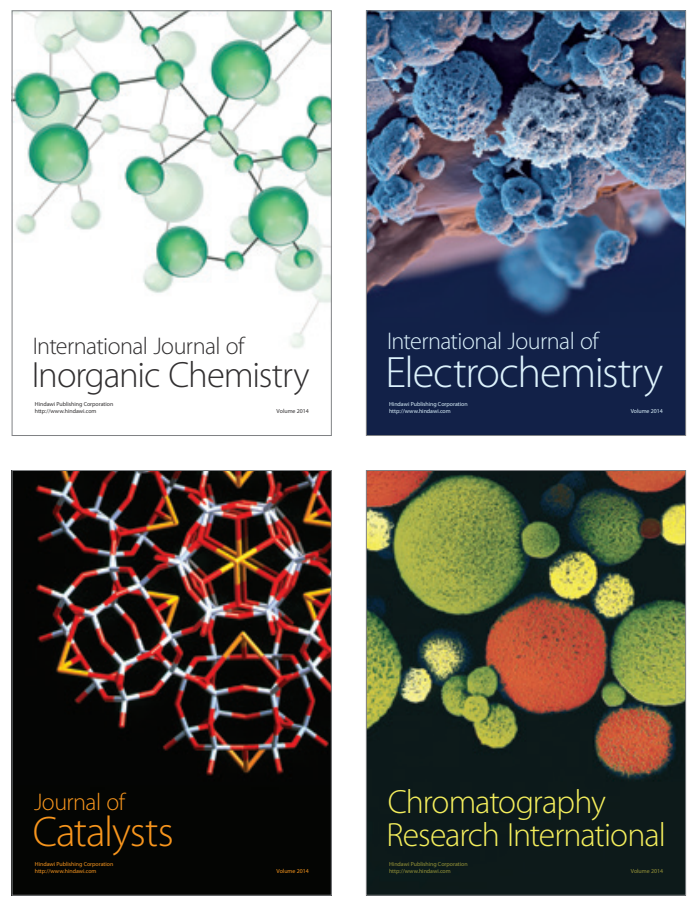
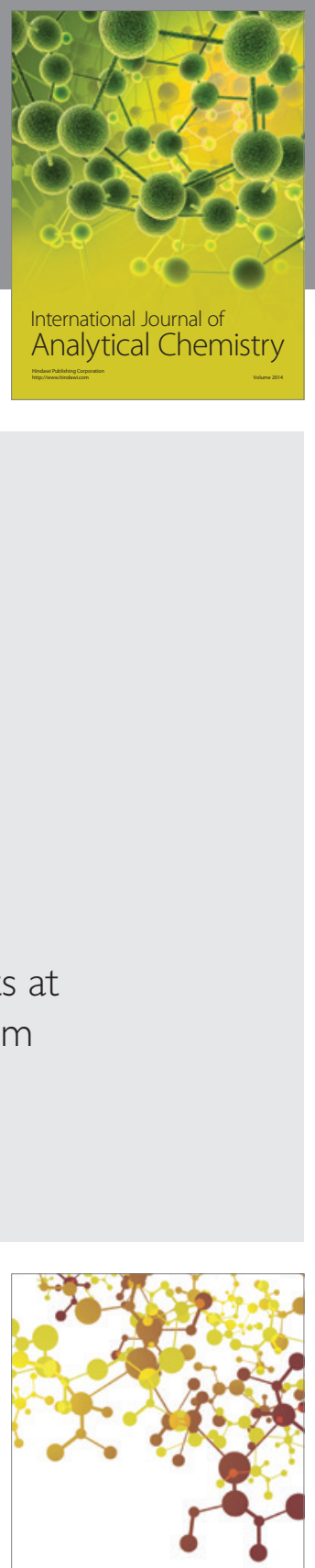

Journal of

Applied Chemistry
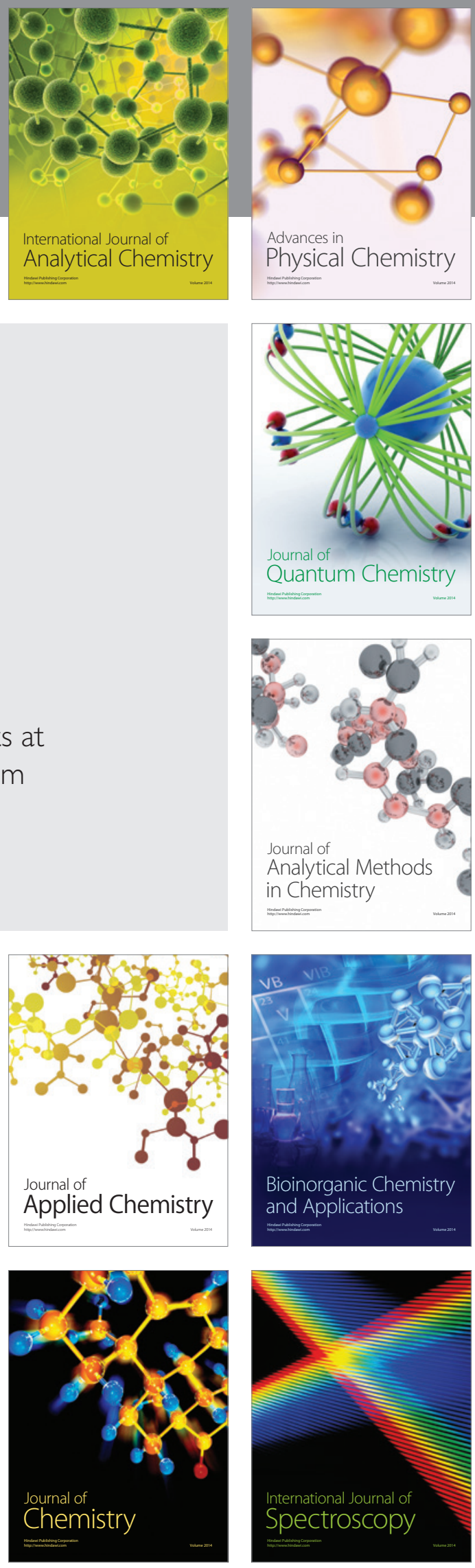